\title{
SEROPREVALENCE OF TOXOPLASMA GONDII IN DOGS AND CATS DOMICILED IN THE WEST OF SANTA CATARINA, BRAZIL
}

\author{
Suelyn Benetti Marques* \\ Eloiza Teles Caldart ${ }^{* *}$ \\ Anna Caroline Fagundes Palavro* \\ Fernanda Pinto Ferreira ${ }^{*+* x}$ \\ Antonella Cordi ${ }^{*+x+\infty}$ \\ Aline Kuhn Sbruzzi Pasquali
}

\begin{abstract}
Toxoplasma gondii is a protozoan with worldwide distribution, responsible for causing toxoplasmosis, a disease that affects mammals, reptiles, amphibians and birds. The objective of this study was to evaluate $T$. gondii seroprevalence in dogs and cats domiciled in cities from West and Serrana mesoregions of Santa Catarina. A total of 338 blood samples, 211 from dogs and 127 from cats were collected and submitted to the indirect haemagglutination technique $(\mathrm{IHT})$ for the detection of anti- $T$. gondii antibodies. Epidemiological questionnaire asking for information related to gender, breed, temperament, behavior, immunity, body index, diet, ectoparasites, access to the streets, hunting habit was applied to the animals owners. The results were $71.89 \%(243 / 338)$ of seropositive animals, being $69.19 \%(146 / 211)$ dogs and $76.38 \%(97 / 127)$ cats. The variable that presented statistical significance was commercial ration for dogs as protection factor. The present study demonstrates a high prevalence of anti- $T$. gondii antibodies in dogs and cats domiciled in West and Serrana mesoregions of Santa Catarina state, Brazil. Through the obtained results we can reinforce the importance of feeding dogs with commercial food, rather than home-made food, avoiding the consumption of raw or undercooked meat by the animals.
\end{abstract}

KEYWORDS: IHT; Risk factors; Toxoplasmosis.

\section{SOROPREVALÊNCIA DE TOXOPLASMA GONDII EM CÃES E GATOS DOMICILIADOS NO OESTE DE SANTA CATARINA, BRAZIL}

RESUMO: 0 Toxoplasma gondii é um protozoário de distribuição mundial, agente etiológico da toxoplasmose, uma doença que afeta mamíferos, répteis, anfíbios e aves. 0 objetivo deste estudo foi avaliar a soroprevalência de T. gondii em cães e gatos de municípios das mesorregiões Oeste e Serrana de Santa Catarina. Um total de 338 amostras de sangue, 211 de cães e 127 de gatos, foram coletados e submetidos à técnica de hemaglutinação indireta (IHT) para a detecção de anticorpos anti-T. gondii. Questionário epidemiológico solicitando informações relacionadas ao gênero, raça, temperamento, comportamento, imunidade, índice corporal, dieta, ectoparasitas, acesso à rua e hábito de caça foi aplicado aos proprietários dos animais. Os resultados foram $71,89 \%(243 / 338)$ dos animais soropositivos, sendo 69,19\% (146/211) cães e 76,38\% (97/127) gatos. A variável que apresentou significância estatística foi o uso ração comercial para cães como fator de proteção. 0 presente estudo demonstra uma alta prevalência de anticorpos anti- $T$. gondii em cães e gatos domiciliados nas mesorregiões 0este e Serrana do estado de Santa Catarina, Brasil. Por meio dos resultados obtidos, reforçamos a importância de alimentar os cães com alimentos comerciais, em vez de alimentos caseiros, evitando o consumo de carne crua ou mal cozida pelos animais.

PALAVRAS-CHAVE: Fatores de risco; HAl; Toxoplasmose.

\footnotetext{
Discente do curso de Medicina Veterinária, Universidade do Oeste de Santa Catarina (UNOESC) Campos Novos, SC, Brasil.

E-mail: suelynbmarques@yahoo.com.br

${ }^{* *}$ Docente Doutora, Universidade Estadual de Londrina (UEL), Londrina, PR, Brasil.

${ }^{* * *}$ Discente do curso de Medicina Veterinária, Universidade do Oeste de Santa Catarina (UNOESC) Campos Novos, SC, Brasil.

${ }^{* * * *}$ Docente Doutora, Universidade Estadual de Londrina (UEL), Londrina, PR, Brasil.

${ }^{* * * * *}$ Profa M.e, Universidade do Oeste de Santa Catarina (UNOESC) Campos Novos, SC, Brasil.

${ }^{* * * * *}$ Prof $^{\mathrm{a}} \mathrm{Dr}^{\mathrm{a}}$, Universidade do Oeste de Santa Catarina (UNOESC) Campos Novos, SC, Brasil.
} 


\section{INTRODUCTION}

Toxoplasmosis is a disease of great relevance that affects a variety of hosts such as mammals, birds, reptiles and amphibians (DUBEY, 1998). According to Fialho, Teixeira and Araújo (2009), this is a disease of importance in public health because of the alterations it causes in human fetuses, and of importance in animal production due to economic losses such as abortion. This disease is caused by the protozoan Toxoplasma gondii, an obligate intracellular parasite known as the most frequent parasite in man and in homeothermic animals (DUBEY, 1998). This parasite has felids as the only definitive hosts, intermediate hosts are all mammals, birds, reptiles, amphibians. There are three infectious stages of $T$. gondii: a rapidly dividing invasive tachyzoite, a slow-dividing bradyzoite in tissue cysts, and an environmental stage, the sporozoite, protected within an 0ocyst (GANGNEUX; DARDÉ, 2012). The main routes of transmission are: ingestion of contaminated fruits and vegetables or water, raw or uncooked meat, unpasteurized milk and through blood transfusions, organ transplants or congenital form (GARCIA, 1999; SILVA, FIGUEIRED0; FREITAS, 2015). Vegetables can be contaminated directly from the faeces of felines (FERREIRA etal., 2018) or through the source of irrigation water from the garden that can be contaminated by the rainwater flow with fecal pathogens (WELLS et al., 2015).

According to Moura et al. (2015), in cats the most common clinical signs are anorexia, fever, lethargy, vomiting, weight loss, abortion, nervous alterations, ocular dysfunctions, cardiac symptoms and, eventually, sudden death. In dogs, toxoplasmosis appears more severe in puppies. The most common clinical signs described are ataxia, diarrhea, and respiratory alteration, such as dyspnoea and cough that may progress to pneumonia, especially in canine distemper virus coinfections, as seen from the opportunistic effect of $T$. gondii as previously mentioned.

Parasitological tests in animals present many difficulties and limitations such as laboratory capacity, cost with examinations, owner's adhesion, lack of awareness of the diagnostic importance. Serological methods are the most used, which consist of the search for IgM and IgG class antibodies. Among the main ones: indirect immunofluorescence test (IFAT), enzyme-linked immunosorbent assay (ELISA), but in addition, the indirect hemagglutination technique (IHT), agglutination by immunoabsorption (ISAGA), and molecular biology reactions can be performed (Bresciani et al., 2008). The IHT is a practical, low cost test, does not require sophisticated equipment and is considered a good method for the screening of toxoplasmosis (COSTA et al., 2007).

The prevalence of antibodies to $T$. gondii is high in most regions, however, the diagnosis is often not performed to quantify them, so the aim of this study was to evaluate the seroprevalence of anti- $T$. gondii antibodies in dogs and cats domiciled in West and Serrana mesoregions of Santa Catarina state, Brazil.

\section{MATERIALS AND METHODS}

\subsection{STUDY AREA}

The state of Santa Catarina is in the southern region of Brazil composed of 95 thousand square kilometers, distributed among 295 municipalities, and the social indexes of this state are among the best in the country. Thirteen cities from West and Serrana mesorregions (Figure 1) were selected to carry out the research project due to the location of the Veterinary Care

\subsection{SAMPLE COLLECTION}

The collection of the samples, the authorization of the use of the material for study purposes and the completion of an epidemiological record occurred from March to December 2018. Blood collection was collected from jugular vein puncture with needle $40 \mathrm{~mm}$ $\mathrm{x} 12 \mathrm{~mm}$ in a collection tube without anticoagulante. After that, the serum was obtained by centrifugation at 2,000 rpm for 10 minutes, being aliquoted and conditioned at $-10^{\circ} \mathrm{C}$ for further analysis. 


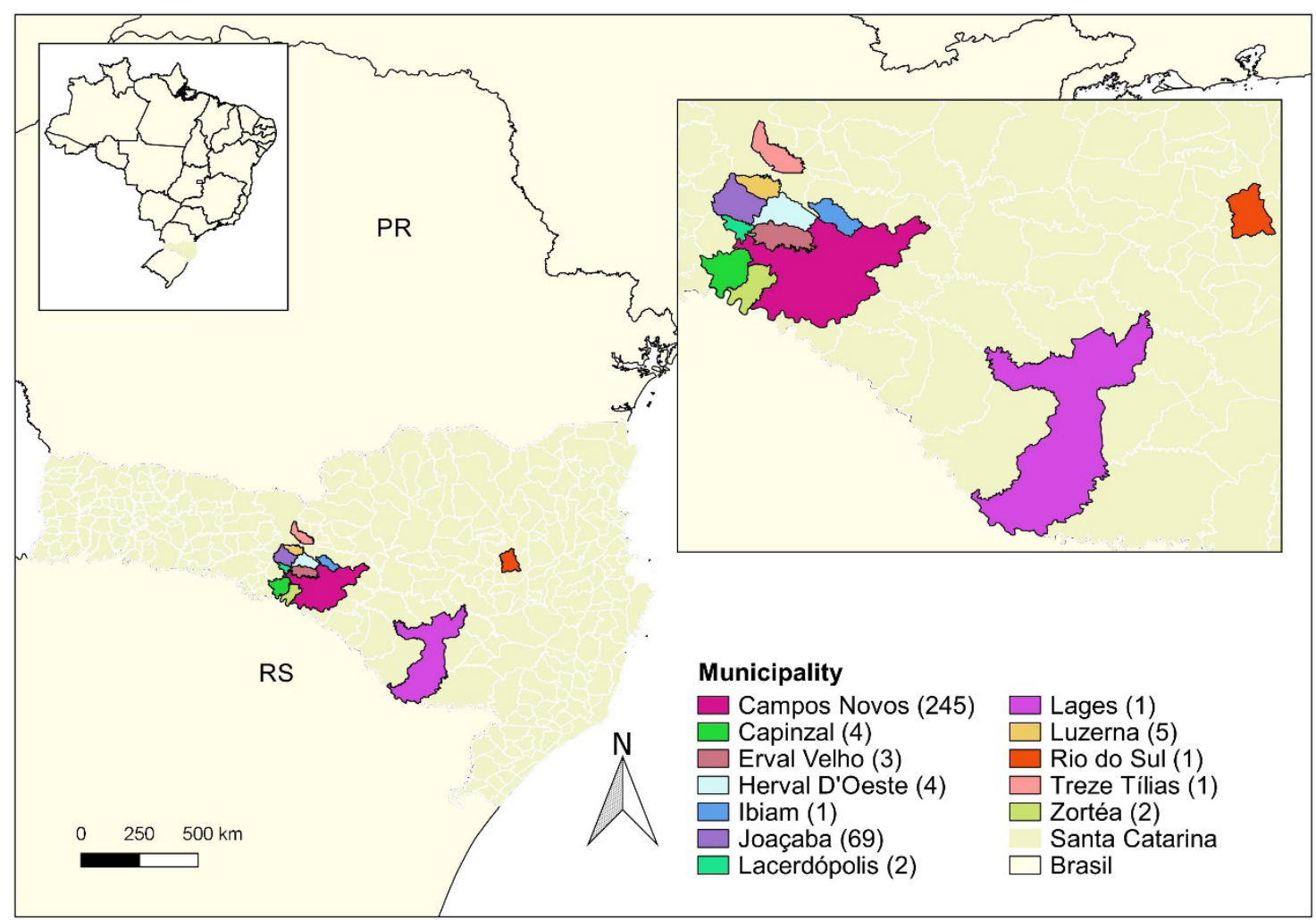

Figure 1. Representative map of the cities of origin of the animals used in the present survey of anti-T. gondi antibodies and the respective number of animals per city.

\subsection{EPIDEMIOLOGICAL QUESTIONNAIRE}

The epidemiological record was a questionnaire answered by the animal guardian and with clinical aspects performed by the veterinarian. The questions evaluated were: species, sex, breed and weight; immunity, such as: vaccinated, dewormed; alternatives related to temperament, such as: docile, fearful or aggressive; behavior, such as: excited, alert, normal, apathetic or comatose; body index: obese, overweight, normal, lean or cachectic; diet: commercial, homemade food or both; presence or absence of ectoparasites, among them: fleas, lice, ticks; with or without access to the street; and hunting habit.

\subsection{SEROLOGICAL TESTS}

Serum samples were tested by IHT for the detection of anti- $T$. gondii antibodies from dogs and cats using Toxotest HAI囚 (Wiener Laboratory), following the manufacturer's recommendations and performing the qualitative and quantitative test. Samples with a titer of 16 or higher were considered as reagents.

\subsection{STATISTI CAL ANALYSIS}

From the test results, the epidemiological data were computed and analyzed through Epilnfo. The statistical significance of the observed and expected results were analyzed by chi-square (2) and Fisher's exact tests, at a significance level of $5.0 \%$. The measure of association was determined by odds ratio (OR) at a $95 \%$ confidence interval (IC).

\subsection{ANIMAL RESEARCH ETHICS COMMITTEE}

This study was approved by the Animal Research Ethics Committee of the University of the West of Santa Catarina under Process № 51/2018 and complied with biosafety and ethical standards. 


\section{RESULTS}

A total of 338 samples were collected, 211 from dogs and 127 from cats. The seropositivity of the animals and their relation to the studied characteristics are visualized in Table 1.

The variable that presented statistical significance was commercial ration for dogs as a protection factor $(p=0.0218)$. Of the dogs fed exclusively on commercial diet, $46.43 \%$ (13/28) were positive, while $88.89 \%(8 / 9)$ from those fed exclusively on homemade food were positive $(\mathrm{OR}=9.23$; IC $96 \%=$ $3.46-24.59)$ and $72.34 \%$ (34/47) from those fed with both were positive $(0 \mathrm{R}=3.01$; IC96\% $=1.13-8.03)$.

The serological titulation for anti- $T$. gondii antibodies ranged from 16 to 262,144, 16 (15.68\%) being the most frequent, followed by $64(11.83 \%)$ and $512(9.47 \%)$ as shown in Table 2.

Table 1. Relation of the seropositive dogs and cats according to the evaluated variables

\begin{tabular}{|c|c|c|}
\hline Variables & Dogs & Cats \\
\hline Soropositive & $69.19 \%(146 / 211)$ & $76.38 \%(97 / 127)$ \\
\hline \multicolumn{3}{|l|}{ Gender } \\
\hline Males & $48.82 \%(103 / 211)$ & $31.50 \%(40 / 127)$ \\
\hline Females & $51.18 \%(108 / 211)$ & $68.50 \%(87 / 127)$ \\
\hline \multicolumn{3}{|l|}{ Breed } \\
\hline Defined breed & $29.38 \%(62 / 211)$ & $1.57 \%(2 / 127)$ \\
\hline $\begin{array}{l}\text { Without a } \\
\text { defined breed }\end{array}$ & $70.62 \%(149 / 211)$ & $\begin{array}{c}98.43 \% \\
(125 / 127) \\
\end{array}$ \\
\hline \multicolumn{3}{|l|}{ Temperament } \\
\hline Docile & $86.90 \%(73 / 84)$ & $43.56 \%(44 / 101)$ \\
\hline Fearful & $11.90 \%(10 / 84)$ & $18.81 \%(19 / 101)$ \\
\hline Aggressive & $1.19 \%(1 / 84)$ & $37.62 \%(38 / 101)$ \\
\hline \multicolumn{3}{|l|}{ Animal behavior } \\
\hline Excited & $8.33 \%(7 / 84)$ & $0.00(0 / 101)$ \\
\hline Alert & $20.24 \%(17 / 84)$ & $77.23 \%(78 / 101)$ \\
\hline Normal & $70.24 \%(59 / 84)$ & $22.77 \%(23 / 101)$ \\
\hline Apathetic & $1.19 \%(1 / 84)$ & $0.00(0 / 101)$ \\
\hline \multicolumn{3}{|l|}{ Body score } \\
\hline Obese & $3.57 \%(3 / 84)$ & $0.00(0 / 101)$ \\
\hline Overweight & $3.57 \%(3 / 84)$ & $3.96 \%(4 / 101)$ \\
\hline
\end{tabular}

\begin{tabular}{|c|c|c|}
\hline $\begin{array}{l}\text { Normal } \\
\text { weight }\end{array}$ & $85.71 \%(72 / 84)$ & $78.22 \%(79 / 101)$ \\
\hline Lean & $7.14 \%(6 / 84)$ & $16.83 \%(17 / 101)$ \\
\hline Cachectic & $0.00(0 / 84)$ & $0.99 \%(1 / 101)$ \\
\hline \multicolumn{3}{|l|}{ Food } \\
\hline $\begin{array}{l}\text { Commercial } \\
\text { ration }\end{array}$ & $33.33 \%(28 / 84)$ & $83.17 \%(84 / 101)$ \\
\hline $\begin{array}{l}\text { Homemade } \\
\text { food }\end{array}$ & $10.71 \%(9 / 84)$ & $1.98 \%(2 / 101)$ \\
\hline $\begin{array}{l}\text { Ration and } \\
\text { homemade } \\
\text { food }\end{array}$ & $55.95 \%(47 / 84)$ & $14.85 \%(15 / 101)$ \\
\hline \multicolumn{3}{|c|}{ Clinical examinations } \\
\hline Ectoparasites & $57.14 \%(48 / 84)$ & $82.18 \%(83 / 101)$ \\
\hline Fleas & $53.57 \%(45 / 84)$ & $82.18 \%(83 / 101)$ \\
\hline $\begin{array}{l}\text { Fleas and } \\
\text { ticks }\end{array}$ & $3.57 \%(3 / 84)$ & $0.00(0 / 101)$ \\
\hline \multicolumn{3}{|c|}{ External conditions } \\
\hline $\begin{array}{l}\text { Access to the } \\
\text { street }\end{array}$ & $67.86 \%(57 / 84)$ & $18.81 \%(19 / 101)$ \\
\hline Residence & $32.14 \%(27 / 84)$ & $81.19 \%(82 / 101)$ \\
\hline \multicolumn{3}{|l|}{ Habit } \\
\hline Hunt & $10.71 \%(9 / 84)$ & $25.74 \%(26 / 101)$ \\
\hline
\end{tabular}

Table 2. Indices of dogs and cats seropositive for anti-T. gondii antibodies according to their titrations. Dilutions up to 1: 262,144 were performed

\begin{tabular}{c|c|c}
\hline Titulation & Dogs & Cats \\
\hline 16 & $22.60(33 / 146)$ & $20.62 \%(20 / 97)$ \\
\hline 32 & $8.22 \%(12 / 146)$ & $5.15 \%(5 / 97)$ \\
\hline 64 & $19.18 \%(28 / 146)$ & $12.37 \%(12 / 97)$ \\
\hline 128 & $11.64 \%(17 / 146)$ & $3.09 \%(3 / 97)$ \\
\hline 256 & $6.85 \%(10 / 146)$ & $10.31 \%(10 / 97)$ \\
\hline 512 & $12.33 \%(18 / 146)$ & $14.43 \%(14 / 97)$ \\
\hline 1,024 & $4.11 \%(6 / 146)$ & $13.40 \%(13 / 97)$ \\
\hline 2,048 & $5.48 \%(8 / 146)$ & $7.22 \%(7 / 97)$ \\
\hline 4,096 & $4,79 \%(7 / 146)$ & $11.34 \%(11 / 97)$ \\
\hline 8,192 & $2.05 \%(3 / 146)$ & $0.00(0 / 97)$ \\
\hline 16,384 & $0.68 \%(1 / 146)$ & $0.00(0 / 97)$ \\
\hline 32,768 & $1.37 \%(2 / 146)$ & $1.03 \%(1 / 97)$ \\
\hline $\mathbf{6 5 , 5 3 6}$ & $0.68 \%(1 / 146)$ & $0.00(0 / 97)$ \\
\hline $\mathbf{2 6 2 , 1 4 4}$ & $0.00(0 / 97)$ & $1.03 \%(1 / 97)$ \\
\hline
\end{tabular}




\section{DISCUSSION}

The seroprevalence for $T$. gondii was $69.19 \%$ (146/211) in dogs, this prevalence is considered high when compared to other studies where seropositivity ranged from $45.1 \%, 57.4 \%, 60.7 \%, 76.4 \%$ using the IFAT method, in the states of Paraíba, Tocantins, Minas Gerais and Roraima respectively (AZEVEDO et al., 2005; RAIMUNDO et al., 2015; GUIMARÃES et al., 2009; CAÑÓN-FRANCO et al., 2004). Lower prevalences or close to those were found by other authors through the HAl method, with $23.1 \%$ and $52.7 \%$ of seropositivity, in the cities of Araçatuba (São Paulo state) and Uberlândia (Minas Gerais state), respectively (BRESCIANI et al., 2008; CABRAL, SILVA, MINEO, FERREIRA; DURAN, 1998).

Of the male dogs evaluated, $66.02 \%(68 / 103)$ were seropositive for $T$. gondii, regarding to females, $72.22 \%$ (78/108) were positive. The sex was not statistically associated to seropositivity, and they could be equally infected, as already mentioned (GERMANO; ERBOLATO; ISHIZUKA, 1985; CABRAL et al., 1998; GAIO, SALINA, MENOZZI; LANGONI, 2014), as well as the breeds, fact also observed by other authors (AZEVEDO et al., 2005; BRESCIANI et al., 2008).

The statiscal analysis of the epidemiological questionnaire indicated commercial diet as a protection factor for dogs. Dogs fed only on homemade feed were 9.23 times more likely to be positive for $T$. gondii when compared to animals fed commercial feed. Dogs with home feed and commercial feed were 3.01 times more likely to be positive for $T$. gondii when compared to those fed only with feed. In general, the commercial feed is a balanced food, with better quality and free of contaminants, improve immunity and reduces the animal access to the raw or undercooked meat. However, there are authors who did not observe statistical difference in relation to this variable (BRESCIANI et al., 2008; CAÑÓN-FRANCO et al., 2004). A study published by Benitez et al. (2017), evaluated the prevalence of humans and their respective dogs and obtained higher statistical seroprevalence in owners (41.54\%) compared to their own dogs (16.32\%), which can be explained by contamination transmitted by food since the exposure to foods such as raw and undercooked meat to dogs was much lower compared to the guardian.

The titers of the seropositive dogs varied between 16 to 65,536 where chronic, or animals in the beginning of the disease, predominated. Similar indexes were obtained in a study conducted by Dantas et al. (2013) in Natal, Rio Grande do Norte, state; they studied the occurrence and risk factors associated with $T$. gondii in 476 dogs, where $11.5 \%$ (55/478) were seropositive, of these $47.2 \%(26 / 55), 22 \%(12 / 55)$, $18 \%(10 / 55), 11 \%(6 / 55)$ and $1.8 \%(1 / 55)$ seropositive animals with titers 64, 128, 256, 512, and 1024 respectively. In another study, conducted by Ferreira et al. (2016), many antibody titers in canines were between 16 (37.45\%) and 64 (34.75\%).

In felines, the seroprevalence of anti-T. gondii antibodies was $76.38 \%(97 / 127)$, results higher than those observed in some studies where seroprevalences ranged from 28.07\% (48/171), 29\% (29/100) 37.9\% $(93 / 245)$ by the IFAT method in the cities of Cascavel, Palotina and Porto Alegre, respectively (ANDRADE et al., 2015; SOUZA et al., 2017; PINTO, ARAÚJO, STOBB; MARQUES, 2009). Pinto et al. (2009), used the HAl method, where $26.9 \%(66 / 245)$ of the cats were seropositive.

Lucas, Hagiwara, Loureiro and Birgel (1999), evaluated 248 domestic cats treated at the Veterinary Hospital of the Faculty of Veterinary Medicine and Animal Science of the University of São Paulo, using IFAT, they observed $17.7 \%$ (44/248) of serum reagents, where $4.8 \%$ (12/250), 5.7\% (14/250), 4.8\% (12/250), $1.2 \%(3 / 250), 1.2 \%(3 / 250)$, presented titers 16,64 , $256,1024,4096$, respectively.

Depending on the host and the via, T. gondii can be infective at any stage of evolution, significantly increasing the risk of infection for domestic animals and humans. There are many prevention methods to reduce cases of toxoplasmosis in both humans and animals, the main ones are: washing hands before meals, incinerating cat feces, protecting pregnant women from contamination, washing well fruits and 
vegetables and, as pointed by this work, avoiding the consumption of raw or undercooked mea (FIALHO et al., 2009). According to Galvão, Vaconcellos, Navarro and Bresciani (2014), preventive methods are the best resources in relation to cases of toxoplasmosis. It is also recommended to avoid or try to abolish the habit of coprophagia observed in some animals, as well as the control of insects and rodents in the environment since they may be carriers of the disease. Don't consume and provide animals with raw meat or raw goat's milk, and the use of available commercial products or foods is indicated.

\section{CONCLUSION}

The present study demonstrates a high prevalence of anti- T. gondii antibodies in dogs and cats domiciled in West and Serrana mesoregions of Santa Catarina State, Brazil. Through the obtained results we can reinforce the importance of feeding dogs with commercial food, rather than home-made food, avoiding the consumption of raw or undercooked meat by the animals.

\section{ACKNOWLEDGMENTS}

We are grateful to Unoesc and the Coordination of the University Scholarship Program of Santa Catarina (UNIEDU) for the opportunity to carry out this study through the Scientific Initiation Grant.

\section{REFERENCES}

ANDRADE, A. C. S.; BITTENCOUR, L. H. F. B.; GODOI, N. F. C.; LIBARDI, K. A.; WESCHENFELDER, D. R. S.; PICOLOTTO, G. C. G. P. Prevalência de anticorpos anti-Toxoplasma gondii em felinos frequentadores de clínicas e hospitais veterinários de Cascavel, Paraná, Brasil. Arquivos de Ciência Veterinária e Zoologia da UNIPAR, v. 18, n. 4, p. 221-224. 2015. Retrieved
Jan 20, 2018. http://www.revistas.unipar.br/index. php/veterinaria/article/view/5747.

AZEVEDO S. S.; BATISTA, C. S. A.; VASCONCELLOS, S. A.; AGUIAR, D. M.; RAGOZO, A. M. A.; RODRIGUES A. A. R.; ALVES, C. J.; GENNARI, S. M. Seroepidemiology of Toxoplasma gondii and Neospora caninum in dogs from the state of Paraíba, Northeast region of Brazil. Research in Veterinary Science, v. 79, p. 51-56. 2005. Retrieved Jan 20, 2018. https:// www.sciencedirect.com/science/article/abs/pii/ S0034528804001936.

BENITEZ, A. N.; MARTINS, F. D. C.; MAREZE, M.; SANTOS, N. J. R.; FERREIRA, F. P.; MARTINS, C. M.; GARCIA, J. L.; MITSUKA-BREGANO, R.; FREIRE R. L.; BIONDO, A. W.; NAVARRO, I. T. Spatial and simultaneous representative seroprevalence of antiToxoplasma gondii antibodies in owners and their domiciled dogs in a major city of southern Brazil. Journals PLOS ONE, v. 12, n. 7, e0180906. 2017. Retrieved Jan 20, 2018. https://journals.plos.org/ plosone/article?id=10.1371/journal.pone.0180906.

BRESCIANI, K. D. S.; COSTA, A. J.; NAVARRO, I. T. N.; TONIOLLO, G. H.; SAKAMOTO, C. A. M.; ARANTES, T. P.; GENNARI, S. M. Toxoplasmose canina: aspectos clínicos e patológicos. Semina: Ciências Agrárias, v. 29, n. 1, p. 189-202. 2008. Retrieved Jan 17, 2018. http://www.producao.usp.br/bitstream/handle/ BDPI/2037/art.GENNARI_toxoplasmose_canina_ aspectosd_clinicos.pdf?sequence $=1$ \&isAllowed=y.

CABRAL, D. D.; SILVA, D. A. 0.; MINE0, J. R.; FERREIRA, F. A.; DURAN, F.P. Frequency of antiToxoplasma gondii antibodies in apparently healthy dogs of the city of Uberlândia, MG. Revista Brasileira de Parasitologia, v. 7, n. 2, p. 87-90. 1998. Retrieved Jan 19, 2018. http://www.ufrrj.br/ rbpv/721998/c7287_90.pdf.

CAÑÓN-FRANCO, W. A.; BERGAMASCHI, D. P.; LABRUNA, M. B.; CAMARGO, L. M. A.; SILVA, J. C. R.; PINTER, A.; GENNARI, S. M. Occurrence of anti Toxoplasma gondii antibodies in dogs in the urban area of Monte Negro, Rondônia, Brazil. Veterinary Research Communications, v. 28, p. 113-118. 
2004. Retrieved Jan 20, 2018. https://link.springer. com/article/10.1023/B:VERC.0000012114.71235.73.

COSTA, T. L.; SILVA, M. G.; RODRIGUES, I. M. X.; BARBARESCO, A. A.; AVELINO, M. M.; CASTRO, A. M. Diagnóstico Clínico e Laboratorial da Toxoplasmose. News Lab, v. 85, p. 88-104. 2007. Retrieved Feb 01, 2019. http://www.researchgate.net/profile/ Ana_Castro25/publication/242196781_Diagnostico_ Clinico_e_Laboratorial_da_Toxoplasmose/ links/00463535e9be657bd4000000.pdf.

\section{DANTAS, S. B. A.; FERNANDES, A. R. F.; SOUZA-} NETO, 0. L.; MOTA, R. A.; ALVES, C. J.; AZEVEDO, S. S. Ocorrência e fatores de risco associados às infecções por Toxoplasma gondii e Neospora caninum em cães no município de Natal, Estado do Rio Grande do Norte, Nordeste do Brasil. Ciência Rural, Santa Maria, v. 43, n. 11, p. 2042-2048. 2013. Retrieved Jan 29, 2019. http://www.scielo.br/pdf/cr/v43n11/ a31513cr2013-0136.pdf.

DUBEY, J. P. Advances in the life cycle of Toxoplasma gondii. International Journal for Parasitology, v. 28, n. 7, p. 1019-1024. 1998. Retrieved Jan 29, 2019. https://www.sciencedirect.com/science/article/abs/ pii/S002075199800023X.

FERREIRA, F. P.; MIURA, A. C.; MAREZE, M.; GARCIA, J. L.; FREIRE, R. L.; NAVARRO, I. T. Frequência de anticorpos anti-Toxoplasma gondii em cães com sinais clínicos compatíveis com toxoplasmose. Ciência Animal Brasileira, v. 17, n. 4, p. 640-646. 2016. Retrieved Jan 29, 2019. http://www.scielo.br/ pdf/cab/v17n4/1809-6891-cab-17-04-0640.pdf.

FERREIRA, F. P.; CALDART, E. T.; FREIRE, R. L.; MITSUKA-BREGANÓ, R.; FREITAS, F. M.; MIURA, A. C.; MAREZE, M.; MARTINS F. D. C.; URBANO, M. R.; SEIFERT A. L.; NAVARRO, I. T. The effect of water source and soil supplementation on parasite contamination in organic vegetable gardens.

\section{Revista Brasileira Parasitologia Veterinária,} v. 27, n. 3, p. 327-337. 2018. Retrieved Jan 27, 2019. http://www.scielo.br/scielo.php?pid=S198429612018005010105\&script=sci_abstract\&tlng=pt.
FIALHO, C. G.; TEIXEIRA, M. C. ; ARAÚJO, F. A. P. Toxoplasmose Animal no Brasil. Acta Scientiae Veterinariae, v. 37, n. 1, p. 1-23. 2009. Retrieved Jan 17, 2018. http://www.ufrgs.br/actavet/37-1/ art805.pdf.

GAIO, F. C.; SALINA, A.; MENOZZI, B. D.; LANGONI, H. Anticorpos anti-Toxoplasma gondii e anti-Neospora caninum em cães da zona rural do município de Botucatu - São Paulo, Brasil. Veterinária e Zootecnia, v. 21, n. 2, p. 288-296. 2014. Retrieved Jan 17, 2019. https://repositorio.unesp.br/ handle/11449/140882.

GALVÃO, A. L. B.; VACONCELLOS, A. L.; NAVARRO, I. T.; BRESCIANI, K. D. S. Aspectos da toxoplasmose na clínica de pequenos animais. Semina: Ciências Agrárias, v. 35, n.1, p. 393-410. 2014. Retrieved Jan 22, 2018. http://www.uel.br/revistas/uel/index.php/ semagrarias/article/viewFile/13470/14256.

GANGNEUX, F.; DARDÉ, M. L. Epidemiology of and Diagnostic Strategies for Toxoplasmosis. Clinical Microbiology Reviews, v. 25, n. 2, p. 264 -296. 2012. Retrieved Jan 19, 2019. https://cmr.asm.org/ content/25/2/264.short.

GARCIA, J. L.; NAVARRO, I. T.; OGAWA, L.; OLIVEIRA, R. C.; KOBILKA, E. Soroprevalência, epidemiologia e avaliação ocular da toxoplasmose humana na zona rural de Jaguapitã (Paraná), Brasil, Paraná, 1999. Revista Panamericana de Salud Publica, v. 6, n. 3, p. 157-163. 1999. Retrieved Jan 17, 2018. http://http://iris.paho.org/ xmlui/bitstream/handle/123456789/8905/0472. pdf? sequence $=1$ \&isAllowed $=\mathrm{y}$ ).

GERMANO, P. M. L.; ERBOLATO, E. B.; ISHIZUKA, M. M. Estudo sorológico da toxoplasmose canina, pela prova de imunofluorescência indireta, na cidade de Campinas, 1981. Revista da Faculdade de Medicina Veterinária e Zootecnia, v. 22, n. 1, p. 53-58. 1985. Retrieved Jan 17, 2019. https://www.revistas.usp.br/ rfmvzusp/article/view/59492.

GUIMARÃES, A. M.; ROCHA, C. M. B. M.; OLIVEIRA, T. M. F. S.; ROSADO, I. R.; MORAIS, L. G.; SANTOS, 
R. R. D. Fatores associados à soropositividade para Babesia, Toxoplasma, Neospora e Leishmania em cães atendidos em nove clínicas veterinárias do município de Lavras, MG. Revista Brasileira de Parasitologia Veterinária, v. 18, n. 1, p. 49-53. 2009. Retrieved Jan 29, 2019. https://www.redalyc. org/pdf/3978/397841474009.pdf.

LUCAS, S.; HAGIWARA, M. K.; LOUREIR0, V. S.; IKESAKI, J. Y. H.; BIRGEL, E. H. Toxoplasma gondii infection in brazilian domestic outpatient cats. Revista do Instituto de Medicina tropical de São Paulo, v. 41, n. 4, p. 221-224. 1999. Retrieved Jan 29, 2019. http://www.scielo.br/scielo. php?pid=S0036 $-46651999000400003 \&$ script $=$ sci arttext.

MOURA, A. B.; TREVISANI, N.; QUADROS, R. M.; LEDO, G.; SOUZA, A. P.; SARTOR, A. A. Anticorpos contra Toxoplasma gondii em gatos apreendidos pelo centro de controle de zoonoses de Lages, SC. Archives of Veterinary Science, v. 20, n. 1, p. 01-07. 2015. Retrieved Jan 17, 2018. http://www.ser.ufpr.br/ veterinary.

PINTO, L. D.; ARAÚJO, F. A. P.; STOBB, N. S.; MARQUES, S. M. T. I. Soroepidemiologia de Toxoplasma gondii em gatos domiciliados atendidos em clínicas particulares de Porto Alegre, RS, Brasil. Tese de Pós-graduação, Universidade Federal do Rio Grande do Sul, Porto Alegre, RS, Brasil. Ciência Rural, v. 39, n. 8, p. 2464-2469. 2009. Retrieved Jan 17, 2019. https://www.lume.ufrgs.br/ handle/10183/12703.

RAIMUNDO, J. M.; GUIMARÃES, A.; MORAES, L. M. B.; SANTOS, L. A.; NEPOMUCENO, L. L.; BARBOSA, S. M.; PIRES, M. S.; SANTOS, H. A.; MASSARD, C. L.; MACHADO, R. Z.; BALDANI, C. D. Toxoplasma gondii e Neospora caninum em cães provenientes de Tocantins: sorologia e fatores associados.

Revista Brasileira de Parasitologia Veterinaria, v. 24, n. 4, p. 475-481. 2015. Retrieved Jan 29, 2019. http://www.scielo.br/scielo.php?pid=S1984$29612015000400475 \&$ script=sci_abstract\&tlng=pt.

ROSA, L. D.; MOURA, A. B.; TREVISANI, N.; MEDEIROS,
A. P.; SARTOR, A. A.; SOUZA, A. P.; BELLATO, V. Toxoplasma gondii antibodies on domiciled cats from Lages municipality, Santa Catarina State, Brazil. Revista Brasileira de Parasitologia Veterinária, v. 19, n. 4, p. 268-269. 2010. Retrieved Feb 14, 2019. http://www.scielo.br/pdf/rbpv/v19n4/a17v19n4.pdf.

SILVA, C. I.; FIGUEIRED0, G. S.; FREITAS, D. R. J. Levantamento sorológico e epidemiológico de toxoplasmose no município de Xanxerê, estado de Santa Catarina. Revista Prevenção de Infecção e Saúde, v. 1, n. 1, p. 1-9. 2015. Retrieved Jan 17, 2018. http://www.sumarios.org/artigo/levantamentosorol\%C3\%B3gico-e-epidemiol\%C3\%B3gicode-toxoplasmose-no-munic\%C3\%ADpio-dexanxer\%C3\%AA-estado-de.

SOUZA, L. Z.; RODRIGUES, R. G. A.; OLIVEIRA, D. A. D.; ROMAN, J. L.; VALENTIM-ZABOTT, M.; PINTO, S. B.; BITTENCOURT, L. H. F. B.; OYAFUSO, M. K. Soroprevalência de Toxoplasma gondii em gatos domiciliados em Palotina, Paraná, Brasil. Arquivos de Ciência Veterinária e Zoologia da UNIPAR, v. 20, n. 3, p. 123-126. 2017. Retrieved Jan 29, 2018. http:// www.revistas.unipar.br/index.php/veterinaria/article/ view/6395.

WELLS, B.; SHAW, H.; HOTCHKISS, E.; GILRAY, J.; AYTON, R.; GREEN, J.; KATZER, F.; WELLS, A.; INNES, E. Prevalence, species identification and genotyping Cryptosporidium from livestock and deer in a catchment in the Cairngorms with a history of a contaminated public water supply. Parasit Vectors, v. 8, n. 66, p. 1-13. 2015. Retrieved Jan 17, 2018. https://parasitesandvectors.biomedcentral.com/ articles/10.1186/s13071-015-0684-x.

Recebido em: 03/10/2019 Aceito em: 21/10/2019 